\title{
Teat End Condition at Different Lactation Periods
}

\author{
Herwin Pisestyani $^{1, a)^{*}}$, RP Agus Lelana ${ }^{2, b)}$, Advis Dwi Saputra ${ }^{3, c)}$, Retno Wulansari ${ }^{4, d)}$, Afton \\ Atabany $^{5, \mathrm{e})}$, Mirnawati B. Sudarwanto ${ }^{1, \mathrm{f})}$ \\ ${ }^{1}$ Department of Animal Diseases and Veterinary Public Health, Faculty of Veterinary Medicine, \\ Bogor Agriculture University, Jalan Agatis Kampus IPB Dramaga Bogor 16680 \\ ${ }^{2}$ Department of Veterinary Clinic Reproduction and Pathology, Faculty of Veterinary Medicine, \\ Bogor Agriculture University, Jalan Agatis Kampus IPB Dramaga Bogor 16680 \\ ${ }^{3}$ Faculty of Veterinary Medicine, Bogor Agriculture University, Jalan Agatis Kampus IPB \\ Dramaga Bogor 16680 \\ ${ }^{4}$ Department of Animal Production and Technology, Faculty of Animal Science, Bogor Agriculture \\ University, Jalan Agatis Kampus IPB Dramaga Bogor 16680 \\ a)*Corresponding author: herwinpi@gmail.com \\ b) Another author: aguslelana@gmail.com \\ c) Another author: advisdwisaputra@ rocketmail.com \\ ${ }^{\mathrm{d})}$ Another author: rtiwul@gmail.com \\ e) Another author: afton.atabany@yahoo.co.id \\ ${ }^{\mathrm{f})}$ Another author: mwanto47@hotmail.com
}

\begin{abstract}
Dairy cattle must be in good health condition as a producer of milk. This study was aimed to assess the influence of hand milking at difference lactation towards teat end condition and hyperkeratosis on dairy cattle in Kunak Bogor and Pasir Jambu Bandung. Object used in the study are clinical healthy dairy cattle in normal lactation and that were selected using the purposive sampling method. As many as 31 from Kunak Bogor and 56 from Pasir Jambu Bandung. Research method was conducted by observation to score teat end condition using Mein and Ohnstad method and the possibility of the occurrence of pathological changes, hyperkeratosis on teat. The analysis was done by descriptive approach and using Chi-Square test. The result showed that the change of teat surface condition and hyperkeratosis was influenced by lactation period. Hopefully, the result of this study could be used by farmer in order to improve milking management and prevent diseases caused by the poor condition of teat.
\end{abstract}

Key words : Hyperkeratosis, teat end condition, teat scoring, dairy cows

\section{INTRODUCTION}

[1];[2] stated, milking activity that are not lege artis causes changes in teat end condition become rough and bad, thus forming keratin ring. [3] also stated that rough or erode teats histologically turn into hyperplasia in the stratum corneum, thus forming hyperkeratosis. According to [3], hyperkeratosis accompanied by several physiological and anatomical factors, such as parity, and udder anatomy may affect the reduction in milk production.

In Indonesia, observation towards teat end condition and hyperkeratosis on dairy cattle has not much been done and reported, therefore research needs to be conducted. West Java Province is one of the central dairy farm in Indonesia, with a population of 135345 cattle and with milk production of 260823 ton/litter [4] (KEMENTAN 2015), therefor the location of the research is focused in West Java. The aim of this study was to assess the impact of manual milking towardsteat end 
condition and the incidence of hyperkeratosis based on parity of dairy cattle located in Kunak Bogor and Pasir Jambu, Ciwidey, Bandung, West Java. This study is expected to be a vehicle to sharpen skills in applying teat assessment methods and giving information to dairy farmers regarding the effects of parity towards teat end condition in dairy cattle. This information is also expected to be the basis of management improvement in milking dairy cattle in Indonesia.

\section{METHOD}

\section{Research Design}

This research used purposive sampling method. With means by choosing farms with dairy cattle on normal lactation and clinically healthy. Normal lactation period of dairy cattle is first month until entering dry cow period at the seventh month of milk production. According to sampling results, 31 dairy cattle were obtain from Cibungbulang Sub-district Regional Dairy Farm Bogor and 56 dairy cattle from Pasir Jambu Subdistrict Regional Dairy Farm Bandung. Observation on research object refers to teat assessment method according to [1]; [5] as shown in Figure 1.

\section{Data Analysis}

Data obtain were analyzed descriptively using Microsoft Excel and further analyzed using ChiSquare test.Analysis results presented in table form.

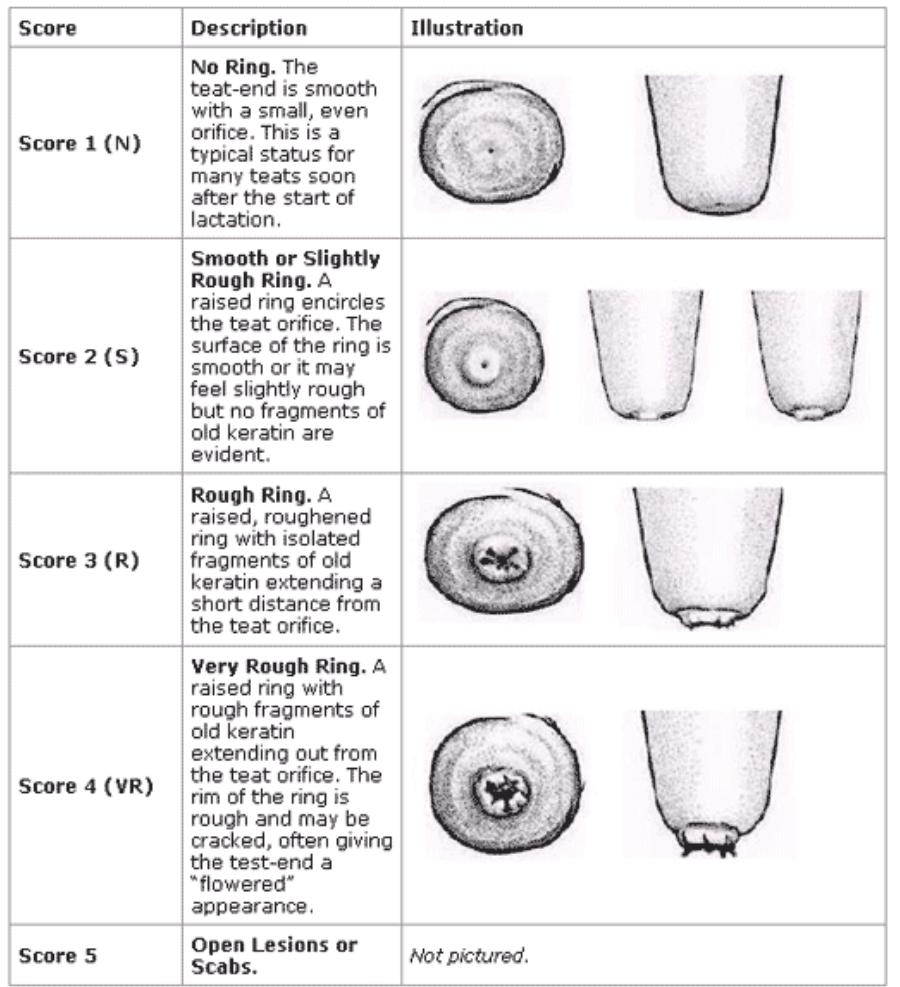

FIGURE 1. Teat end condition assessment method

\section{RESULT AND DISCUSSION}

\section{Teat End Condition}

From Table 1 it can be concluded the older the lactation periods, more changes on teat surface. For example, teat end condition from cow on first, second, and third lactation generally looks normal (No Ring). At fourth and fifth lactation, teat end have experienced minor changes in the 
form of smooth or slightly rough keratin ring. On sixth lactation teat endexperience major changes in the form of rough keratin ring. On seventh lactation experience major changes in the form of very rough keratin ring and some experience pathological change in the form of hyperkeratosis. This is presumably due to the increased frequency of milking. Results are similar to the research results of [3]; [6] which states that changes in teat end condition of dairy cattle in older lactation are worse than dairy cow in earlier lactation.

Table 1 Percentage of teat end condition and hyperkeratosis incidence by lactation period

\begin{tabular}{|c|c|c|c|c|c|c|c|}
\hline \multirow[b]{2}{*}{ Lactation } & \multirow[b]{2}{*}{ (n) cow } & \multicolumn{5}{|c|}{ Teat end condition } & \multirow[b]{2}{*}{$\begin{array}{c}\text { Hyperkeratosis } \\
(\%)\end{array}$} \\
\hline & & $\begin{array}{l}(\mathrm{n}) \\
\text { teat }\end{array}$ & $\begin{array}{l}\text { Normal } \\
(\%)\end{array}$ & $\begin{array}{c}\text { Smooth/ } \\
\text { slightly rough } \\
(\%)\end{array}$ & $\begin{array}{c}\text { Rough } \\
(\%)\end{array}$ & $\begin{array}{c}\text { Very } \\
\text { rough }(\%)\end{array}$ & \\
\hline 1 & 9 & 36 & 66.7 & 25.0 & 8.3 & 0 & 5.6 \\
\hline 2 & 17 & 68 & 60.3 & 30.9 & 8.8 & 0 & 7.4 \\
\hline 3 & 23 & 92 & 57.6 & 31.5 & 10.9 & 0 & 14.1 \\
\hline 4 & 20 & 80 & 40 & 45 & 15 & 0 & 21.3 \\
\hline 5 & 10 & 40 & 30 & 47.5 & 17.5 & 5 & 32.5 \\
\hline 6 & 4 & 16 & 25 & 37.5 & 25 & 12.5 & 50 \\
\hline 7 & 4 & 16 & 25 & 31.3 & 18.7 & 25 & 62.5 \\
\hline
\end{tabular}

Associated with [7] theory which stated that cattle are said to be in a problem if more than $20 \%$ of cattle have teat end with rough keratin ring or more than $10 \%$ with very rough keratin ring, therefor by looking at Table 1 it can be said that dairy cattle at sixth and seventh lactation faces problems.

\section{Effect of Lactation Age Towards Teat Surface}

As we know that on every lactation age changes in milk production occurs. With that in consideration [8] divided lactation period as follows: first lactation until the second is referred to the early production period, third lactation until the fifth is referred to the peak production period and sixth lactation until the seventh is referred to the end of production. The grouping is implemented in Table 2.

According to Table 2 it can be learned that normal teat end condition at early production $(62.5 \%)$ is greater compared to lactation at its peak production age $(45.8 \%)$ and lactation at the end production $(21.9 \%)$. Smooth/slightly rough teat end condition at peak production $(39.6 \%)$ is greater compared to lactation at early production $(28.8 \%)$ and lactation at end production $(34.4 \%)$. Rough teat end condition at end production $(28.1 \%)$ is greater compared to early production $(8.7 \%)$ and peak production $(13.7 \%)$. In condition of very rough teat surface at end production $(15.6 \%)$ is greater compared to early production $(0 \%)$ and peak production $(9 \%)$. Statistical test results of data obtained indicate a probability value of $0000(<\mathbf{0 . 0 5})$, which means that there is an effect between the ages of lactation towards teat end condition. 
Table 2. The effect of lactation period towards teat end condition

\begin{tabular}{|c|c|c|c|c|c|c|c|c|c|c|c|}
\hline \multirow{3}{*}{ Lactation } & \multicolumn{8}{|c|}{ Teat end Condition } & \multirow{2}{*}{\multicolumn{2}{|c|}{ Total }} & \multirow{3}{*}{$p V$} \\
\hline & \multicolumn{2}{|c|}{ Normal } & \multicolumn{2}{|c|}{$\begin{array}{c}\text { Smooth/slightl } \\
\text { y rough }\end{array}$} & \multicolumn{2}{|c|}{ Rough } & \multicolumn{2}{|c|}{ Very rough } & & & \\
\hline & $\begin{array}{l}\text { (n) } \\
\text { teat }\end{array}$ & $\%$ & $\begin{array}{l}\text { (n) } \\
\text { teat }\end{array}$ & $\%$ & $\begin{array}{l}\text { (n) } \\
\text { teat }\end{array}$ & $\%$ & $\begin{array}{l}\text { (n) } \\
\text { teat }\end{array}$ & $\%$ & $\begin{array}{l}\text { (n) } \\
\text { teat }\end{array}$ & $\%$ & \\
\hline $\begin{array}{c}\text { Early } \\
\text { production }\end{array}$ & 65 & $\begin{array}{c}62.5 \\
\%\end{array}$ & 30 & $\begin{array}{c}28.8 \\
\%\end{array}$ & 9 & $8.7 \%$ & 0 & $0 \%$ & 104 & $\begin{array}{c}100 \\
\%\end{array}$ & \\
\hline $\begin{array}{c}\text { Peak } \\
\text { production }\end{array}$ & 97 & $\begin{array}{c}45.8 \\
\%\end{array}$ & 84 & $\begin{array}{c}39.6 \\
\%\end{array}$ & 29 & $13.7 \%$ & 2 & $9 \%$ & 212 & $\begin{array}{c}100 \\
\%\end{array}$ & \\
\hline $\begin{array}{c}\text { End } \\
\text { production }\end{array}$ & 7 & $\begin{array}{c}21.9 \\
\%\end{array}$ & 11 & $\begin{array}{c}34.4 \\
\%\end{array}$ & 9 & $28.1 \%$ & 5 & $15.6 \%$ & 32 & $\begin{array}{c}100 \\
\%\end{array}$ & $0.000 *$ \\
\hline Total & 169 & $\begin{array}{c}48.6 \\
\%\end{array}$ & 125 & $\begin{array}{c}35.9 \\
\%\end{array}$ & 47 & $13.5 \%$ & 7 & $2 \%$ & 348 & $\begin{array}{c}100 \\
\%\end{array}$ & \\
\hline
\end{tabular}

*shows there is visible effect on $p V(<0.05)$

\section{Milking Management}

From Table 1 and Table 2 once again can be concluded that lactation period effects change in teat condition and incidence of hyperkeratosis. Teat end condition that experience this change is thought to be the course of the milking process. The higher the milking frequency in parallel with lactation period, the more damage of teat end occurs. The more damage on the teats end, the more keratin ring forms as a respond to healing of the tissue. However, this process also affects the flexibility of the teat as so it invites new problems such as broken teat surface which then becomes an entry port for pathogenic bacteria [9]; [10].

Apart from milking management factor, the process of hyperkeratosis according to [5] is effected by weather, climatic conditions, environment, milk production, lactation age, parity and genetic. [3] added that other than those factors above, hyperkeratosis is also effected by over use of disinfectant which results in skin irritation of the teat, teat become rough, chapped, dry, wounded, and easily infected by bacteria such as Staphylococcus aureus. The impact of it all causes difficulty in healing of the dairy cow teats.

Factors that cause hyperkeratosis as mentioned by [5] are also proven in this study. This is partly shown with the presence of the dry season as an influence factor towards weather in causing lack of water supply and bad cattlehed environment sanitation so that dairy cow teat are easily susceptible to infectious pathogens.

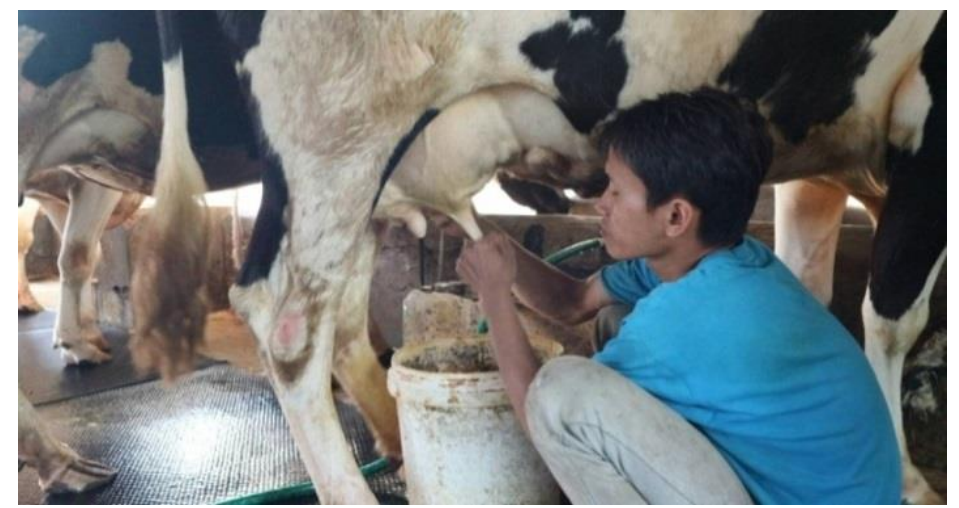

Figure 2. Milking is done traditionally by an Indonesian dairy farmer

[5]; [11], who stated that traditional milking using two fingers (Strip Method) will affect the anatomical shape of the udder and teat. Two finger milking (Strip Method) is milking with the thumb and forefinger by shifting from the base of the teat downwards while massaging, loosened then press upward. This two finger milking method can inflict various problems, including occurrence of subclinical mastitis if used continuously until the cow reached old age. Weakness in 
milking this way is that the udder and teats are always wet, easily wounded and the teats anatomy will slowly become longer. Long teats will easily develop subclinical mastitis compared to shorter teats therefore teat length can be used as a predisposing factor of subclinical mastitis [12]. Milking with this method is applied at Kunak dairy farm Cibungbulang Bogor and Pasir Jambu Ciwidey Bandung, West Java.

Other than milking, age factor also affects the occurrence of subclinical mastitis. [13] study about the factors that cause mastitis showed that age positively associates to the occurrence of subclinical mastitis, meaning subclinical mastitis often affects cattle of old age. The older the age of the cattle, especially cattle with high milk production, the more loosely the teat sphincter, making it easier to become infected because the ability of the sphincter to resist the entry of germs is reduced. The higher the milk production, the longer the time needed for the sphincter to close properly [14].

\section{CONCLUSION}

The results showed that lactation period has a significant affect towards changes in teat end condition and hyperkeratosis.

\section{REFERENCE}

1. G. A. Mein, F. Neijenhuis, W. F. Morgan, D. J. Reinemann, J. E. Hillerton, J. R. Baines, I. Ohnstad, M. D. Rasmussen, L. Timms, J. S. Britt, R. Farnsworth, N. B. Cook, "Evalution of bovine teat condition in commercial dairy herds: 1. non-infectious factors", Proceedings NMC and AABP meeting (Vancouver, 2001), pp. 347.

2. J. H. Paduch, E. Mohr, V. Krömer. The association between teat end hyperkeratosis and teat canal microbial load in lactating dairy cattle.Vet.Microb. 158, 353-359(2012).

3. F. Neijenhuis, H. W. Barkema, H. Hogeveen, J. P. T. M. Noorhizen, Relationship between teat-end callosity and occurrence of clinical mastitis.J. Dairy. Sci. 84, 2664-2672 (2001).

4. [KEMENTAN] Kementerian Pertanian. 2015. Basis data statistic pertanian [internet]. Jakarta (ID): KEMENTAN RI [diunduh 2016 Nov 7]. Tersediapada: www.pertanian.go.id

5. I. Ohnstad, G. A. Mein, F. Neijenhius, J. E. Hillerton, J. R. Baines, R. Farnsworth,"Assessing the scale of teat end problems and their likely causes"Annuaul NMC Proceedings $42^{\text {nd }}$ (Ford Worth, Texas, 2003).

6. D. E. Gleeson, B. O'Brien, L. Boyle, B. Earley, Effect of milking frequency and nutritional level on aspects of the health and welfare of dairy cows. Animal 1, 125-132(2007).

7. J. H. Kirk,Teat End Conditions and Scoring Systems, (School of Veterinary Medicine, University of California Davis, Extension Veterinarian, Tulare, 2002).

8. Soeharsono,Laktasi. ProduksidanPerananSusuBagiKehidupanManusia (WidyaPadjajaran,Bandung, 2008),pp. 192-194.

9. R. J. Grindal, J. E. Hillerton, Influence of milk flow rate on new intramammary infection in dairy cows,J. Dairy Res.58,263-268 (1991).

10. T. Bobić, P. Mijić, G. Vučković, M. Gregić, M. Baban, V. Gantner, Morphological and Milkability Breed Differences of Dairy Cows (Faculty of Agriculture, University of Osijek, OsijekCrotia, 2014).

11. D. W. Lukman, M. Sudarwanto, A. W. Sanjaya,T. Purnawarman, H. Latif, R.R. Soejoedono, H. Pisestyani, Higiene Pangan. (Bagian Kesehatan Masyarakat Veteriner Departemen Ilmu Penyakit Hewan dan Kesmavet, Fakultas Kedokteran Hewan Institut Pertanian Bogor,Bogor, 2009). 
12. Y. N. Septiani, "Panjang putting dan periode laktasi sebagai factor predisposisi mastitis subklinis pada sapi perah di KPSBU Lembang, kabupaten Bandung” DVM. Skripsi, Institut Pertanian Bogor, 2013.

13. E. Sutarti, S. Budiharta, B. Sumiarta, Prevalensi dan faktor-faktor penyebab mastitis pada sapi perah rakyat di Kabupaten Semarang, Provinsi Jawa Tengah. J.Sain. Vet.21, 43-49 (2003).

14. Subronto,IlmuPenyakitTernak (Mamalia). Ed ke-2. (GadjahMada University Press, 2003), pp. 224. 